\title{
ESTIMASI SERAPAN KARBON PADA HUTAN MANGROVE DESA BEDONO, DEMAK, JAWA TENGAH
}

\author{
Fella Suffa Azzahra ${ }^{a}$, Suryanti Suryantia,", Sigit Febrianto ${ }^{a}$ \\ ${ }^{a}$ Manajemen Sumberdaya Perairan, Fakultas Perikanan dan Ilmu Kelautan, \\ Universitas Diponegoro \\ *Koresponden penulis : fellasuffa3@gmail.com
}

\begin{abstract}
Abstrak
Kadar karbondioksida $\left(\mathrm{CO}_{2}\right)$ di alam semakin bertambah seiring dengan berkembangnya peradaban manusia. Disisi lain, hutan mangrove dapat menyerap dan menyimpan karbon dalam jumlah yang besar dan waktu yang lama, sehingga mampu berperan dalam mitigasi perubahan iklim. Tujuan dari penelitian ini adalah mengetahui kandungan karbon yang ada pada tegakan, sedimen, dan serasah daun mangrove serta tingkat penyerapan $\mathrm{CO}_{2}$. Penelitian ini dilaksanakan pada November 2019 di kawasan ekosistem hutan mangrove Desa Bedono, Sayung, Demak. Metode yang digunakan dalam pengambilan sampel adalah metode purposive sampling di 4 stasiun dengan total titik sampling 12. Analisis karbon menggunakan persamaan allometrik untuk menghitung simpanan karbon pada tegakan, kemudian untuk sedimen dan serasah daun menggunakan metode Loss on Ignition (LOI). Hasil yang diperoleh yaitu ditemukan 2 jenis mangrove pada lokasi penelitian yaitu Avicennia marina, dan Rhizopora mucronata. Nilai kerapatan jenis masing-masing spesies yaitu $4875 \mathrm{indv} / \mathrm{ha}$, dan 200 indv/ha. Persentase penutupan rata-rata sebesar $76,94 \%$. Kandungan karbon yang ada pada tegakan, sedimen, dan serasah daun mangrove masing-masing yaitu mangrove sebesar 190,257 ton karbon/ha, 480,608 ton carbon/ha, dan 0,00165 ton carbon/ha /hari.
\end{abstract}

Kata kunci : Desa Bedono Demak, mangrove, serapan $\mathrm{CO}_{2}$, stok karbon

\begin{abstract}
Carbon dioxide (CO2) levels in nature are increasing along with the development of human civilization. Mangrove forests can absorb and store carbon in large quantities and a long time so that it can become a strategy in mitigating climate change. The purpose of this research is to calculate biomass and carbon stock in stand, sediments, and mangrove leaf litter; know the supporting factors of mangrove ecosystem sustainability. This research was carried out November 2019 in the area of mangrove forest ecosystems in the Bedono Village, Demak. The method used in sampling is the purposive sampling method at 4 stations with a total sampling point of 12. Carbon analysis uses allometric equations to calculate carbon deposits in stands, sediments and leaf litter using the Loss on Ignition (LOI) method. The results obtained are found 2 types of mangroves at the study site, Avicennia marina, and Rhizopora mucronata. The species density value of each species is $4875 \mathrm{indv} / \mathrm{ha}$, and $200 \mathrm{indv} / \mathrm{ha}$. The percentage of closure averaged 76.94\%. The carbon content in mangrove stands, sediments, and litter of mangrove leaves are 190,257 tons / ha, 480,608 tons / ha, and 0,00165 tons / ha / day, respectively.
\end{abstract}

Keywords : $\mathrm{CO}_{2}$ uptake, Carbon stock, mangroves, Bedono Village

\section{PENDAHULUAN}

Pemanasan global merupakan salah satu isu dunia saat ini, ditandai dengan meningkatnya suhu rata-rata permukaan bumi terkait dengan gas rumah kaca. $\mathrm{CO}_{2}$ merupakan salah satu gas rumah kaca penyebab utama pemanasan global dan perubahan iklim. Pemanasan global merupakan kejadian dimana terjadinya peningkatan suhu di atmosfer, laut dan daratan. Para ilmuwan menyatakan pemanasan global disebabkan oleh aktivitas manusia (antropogenik) dalam melakukan pembakaran bahan bakar fosil, seperti batubara, minyak bumi, dan gas alam yang sangat potensial melepas karbon dioksida $\left(\mathrm{CO}_{2}\right)$ dan gas-gas lainnya yang dikenal sebagai gas rumah kaca (GRK) ke atmosfer [1]. Penyebab utama terjadinya pemanasan global adalah peningkatan emisi gas rumah kaca seperti karbon dioksida 
$\left(\mathrm{CO}_{2}\right)$ dan metana $\left(\mathrm{CH}_{4}\right)$ yang dihasilkan dari sektor industri, aktivitas transportasi, dan kegiatan pertanian maupun peternakan. Salah satu upaya mitigasi yang dilakukan untuk mengurangi konsentrasi $\mathrm{CO}_{2}$ di atmosfer adalah dengan konsep blue carbon dimana terdapat 3 ekosistem utama yang memiliki peranan dalam menyimpan karbon baik pada jaringan maupun di dalam sedimen antara lain ekosistem padang lamun, rawa asin dan mangrove [1].

Salah satu ekosistem pesisir yang memiliki kemampuan paling tinggi dalam menyerap $\mathrm{CO} 2$ adalah hutan mangrove merupakan salah satu ekosistem pesisir perairan tropis yang memiliki berbagai manfaat potensial baik bagi lingkungan serta manusia. Hutan mangrove memiliki salah satu fungsi yang sangat penting sebagaimana hutan lainnya yaitu sebagai penyerap dan penyimpan karbon (C). Hutan mangrove berperan dalam upaya mitigasi akibat pemanasan global karena hutan mangrove dapat berfungsi sebagai penyimpan karbon (C) [2]. Hutan mangrove dapat menyimpan lebih dari tiga kali rata-rata penyimpanan karbon per hektar oleh hutan tropis daratan [3]. Fungsi optimal penyerapan karbon oleh mangrove mencapai hingga $77,9 \%$, dimana karbon yang diserap tersebut disimpan dalam biomassa mangrove yaitu pada beberapa bagian seperti pada batang, daun, dan sedimen [4]. Fungsi ekologis pada hutan mangrove diantaranya adalah sebagai sumber karbon tinggi, hal ini menjadi pertimbangan penting untuk upaya konservasi kawasan ini. Indonesia sendiri memiliki area hutan mangrove yang luas. Stok karbon global rata-rata yang dimiliki oleh ekosistem mangrove diperkirakan mencapai $956 \mathrm{Mg} \mathrm{C} \mathrm{ha}^{-1}$, yang jauh lebih tinggi daripada hutan hujan tropis, rawa gambut, rawa asin, dan padang lamun [5]. simpanan karbon di hutan mangrove lebih tinggi dibandingkan simpanan karbon pada tipe hutan lainnya, dimana simpanan karbon terbesar terdapat pada sedimen mangrove. Daun dan ranting pohon mangrove yang gugur didekomposisi oleh mikroorganisme, dan menjadi salah satu sumber bahan organik pada sedimen mangrove.

Seluruh luas wilayah Kabupaten Demak 89,743 Ha, pada tahun 2010 luas hutan mangrovenya sebesar $2.089,45$ Ha sedangkan pada tahun 2015 hutan mangrovenya seluas 2.021,28 Ha. Penelitian mengenai estimasi karbon tersimpan dalam vegetasi mangrove penting dilakukan untuk mengetahui seberapa besar kawasan hutan mangrove tersebut mampu menyerap $\mathrm{CO}_{2}$ dari udara, sehingga hal tersebut dapat menunjang kegiatan pengelolaan kawasan secara berkelanjutan dalam kaitannya dengan pengurangan konsentrasi $\mathrm{CO}_{2}$ di atmosfer. Jika telah mengetahui besarnya cadangan karbon tersimpan pada hutan maka dapat diketahui besarnya fungsi kawasan tersebut dalam mitigasi perubahan iklim. Usaha untuk mengetahui potensi hutan mangrove sebagai pengikat karbon dan peranannya dalam mitigasi perubahan iklim dapat dilakukan melalui penelitian mengenai estimasi serapan karbon pada hutan mangrove yang terserap melalui above ground, below ground, dan sedimen.

\section{MATERI DAN METODE}

\section{Materi Penelitian}

Materi yang akan digunakan pada penelitian ini adalah data kerapatan, biomassa tegakan, sedimen, dan serasah daun mangrove. Alat dan bahan yang digunakan dalam pengambilan data di lapangan diantaranya adalah alat tulis untuk mencatat hasil pengamatan di lapangan, meteran jahit untuk mengukur $\mathrm{DBH}$, sediment corer untuk pengambilan sedimen, litter trap untuk menangkap serasah daun yang jatuh, GPS untuk menentukan titik sampling, rol meter untuk membuat transek, kantong sampel untuk meletakkan sampel, kertas label untuk memberikan tanda pada sampel yang telah diambil. Alat yang digunakan untuk pengujian di laboratorium yaitu oven, neraca analitik, cawan porselen, furnace.

\section{Metode Pengambilan Data}

Penelitian dilakukan pada bulan November 2019 di kawasan mangrove Desa Bedono. Penelitian ini menggunakan metode penelitian deskriptif eksploratif. Metode deskriptif merupakan salah satu metode yang dilakukan dengan cara mengumpulkan data dari hasil interview, catatan lapangan, foto, dokumen pribadi, dan dokumen resmi. Pengambilan data pada penelitian ini diambil dari 4 stasiun penelitian dengan masing-masing stasiun terdiri dari 3 titik. Gambaran lokasi penelitian tersaji pada Gambar 1. 


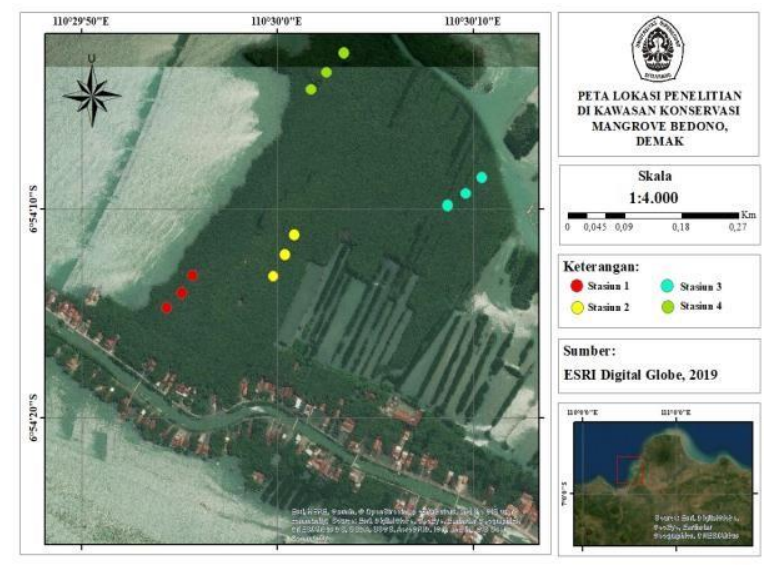

Gambar 1. Peta lokasi penelitian

\section{Metode Analisis Data}

\section{Kandungan Karbon pada Tegakan Mangrove}

Data yang digunakan dalam mengukur biomassa tegakan mangrove ialah diameter batang (dbh) dan tinggi pohon. Metode pengukuran dbh dan tinggi tegakan mangrove. Pengambilan data diameter pohon mangrove digunakan untuk pengukuran biomassa. Pengukuran diameter pohon dilakukan dengan cara mengukur diameter breast height (DBH) diameter setinggi dada atau kurang lebih $1.3 \mathrm{~m}$ dari permukaan tanah [6].

Data diameter dan tinggi tegakan mangrove kemudian diolah menggunakan persamaan alometrik untuk mengetahi biomassa tegakan. Persamaan alometrik biomassa yang digunakan pada tegakan mangrove tersaji dalam tabel 1.

Tabel 1. Model allometrik above ground biomass

\begin{tabular}{lc}
\hline Jenis spesies & Model allometrik \\
\cline { 1 - 2 } A. marina & $\mathrm{B}=0.1848 * \mathrm{D}^{2.3524}$ \\
Rhizophora mucronata & $\mathrm{B}=0.128 * \mathrm{D}^{2.60}$ \\
\hline
\end{tabular}

Menurut IPPC (2007) bahwa karbon yang terkandung dalam bahan organik yaitu $47 \%$, sehingga estimasi jumlah karbon tersimpan yaitu dengan mengalikan $47 \%$ atau 0,47 dengan biomassa seperti persamaan berikut:

$$
\text { Cn }(\text { ton/ha })=\text { Biomasa }(\text { ton/ha }) \times 0.47
$$

\section{Uji Karbon pada Sedimen Mangrove}

Pengambilan sampel sedimen dilakukan pada setiap titik dengan menggunakan sedimen core modifikasi dengan pipa PVC ukuran $50 \mathrm{~cm}$ dan diameternya $5 \mathrm{~cm}$. Analisis kandungan karbon organik tanah menggunakan metode Loss On Ignition (LOI). Metode LOI merupakam metode untuk mengukur kadar organik pada sedimen dengan menimbang berat sampel yang hilang setelah pemakaian [7]. Tahapan analisis sebagai berikut [8]:

1. Sampel sedimen ditempatkan ke dalam cawan aluminium, kemudian dimasukkan ke dalam oven dengan suhu $60^{\circ} \mathrm{C}$ selama 48 jam.

2. Setelah kering, sampel dihaluskan dengan mortar agar homogen sebelum dilakukan pembakaran. Setiap sub sampel yang sudah halus ditempatkan ke dalam kantong ziper (kantong plastik klip).

3. Sampel ditimbang \pm 2 gram, kemudian ditempatkan pada crucible porcelain. Kemudian sampel dimasukkan ke dalam furnace dan dibakar dengan suhu $450^{\circ} \mathrm{C}$ selama 4 jam, kemudian ditimbang kembali.

4. Pengukuran bahan organik sedimen dilakukan dengan menggunakan metode LOI (Loss on Ignition) dengan cara sebagai berikut:

$$
\text { Bahan organik }=\frac{(W t-C)-(W a-C)}{W t-ᄃ .} \times 100 \%
$$

\section{Keterangan}

Wt : Berat total crucible dan sampel sebelum dikeringkan

C : Berat crucible kosong

Wt : Berat total crucible dan sampel setelah dikeringkan

Data yang dihitung adalah volume sampel sedimen, bulk density dan persentase karbon organik pada sedimen. Perhitungan yang digunakan dalam analisis data menurut [8] yaitu:

1. Bulk density tanah merupakan berat partikel persatuan volume tanah beserta porinya. Rumus yang digunakan untuk menghitung bulk density (BD) adalah

$$
\text { Soilbulkdensity }(g \quad)=\frac{\text { leving }(g)}{\text { inume }\left(\mathrm{cm}^{3}\right)}
$$

2. Densitas Karbon (C) dihitung dengan menggunakan persamaan:

$$
\text { Soil C density }\left(\mathrm{gCcm}^{-3}\right)=\% C X B D
$$

3. Kandungan karbon pada tanah diestimasi dengan persamaan:

SoilC $\left(M g h a^{-1}\right)=B D x S D I$ 


\section{(SoilDepthInterval) X\%C}

Apabila analisis hanya menghasilkan kandungan bahan organik (misalnya dengan metode LOI). Maka kandungan $\mathrm{C}_{\text {org }}$ tanah diasumsikan 1/1,724 dari kandungan bahan organik tanah. Apabila jenis substrat mempunyai kandungan bahan organik $98 \%$ maka $\mathrm{C}_{\text {org }}=98 \% / 1,724$. Hasil perhitungan karbon tanah kemudian dikonversikan menjadi ton/ha dengan mengalikan 100 (faktor konversi dari $\mathrm{g} / \mathrm{cm}^{2}$ ke ton/ha) [7].

\section{Uji Kandungan Karbon pada Serasah Daun}

Pengambilan sampel serasah dilakukan dengan menggunakan jaring penangkap serasah yang dipasang selama 7 hari di setiap titiknya. Perhitungan untuk melakukan estimasi kandungan karbon pada serasah, terlebih dahulu menentukan estimasi kandungan karbon pada bahan organik dalam hal ini adalah serasah daun mangrove. Penentuan kadar karbon organik dilakukan menggunakan cara pengabuan pada suhu $550-600^{\circ} \mathrm{C}$, sehingga bahan organik menjadi $\mathrm{CO}_{2}$ dan logam menjadi oksida logamnya. Bobot bahan yang hilang merupakan bahan organik yang dapat dikonversi menjadi kadar C-organik setelah dikalikan faktor 0,58 [9].

Sampel serasah diambil sebanyak $\pm 1,5$ gram untuk dimasukkan ke dalam furnace (tanur), mula-mula diabukan pada suhu $300^{\circ} \mathrm{C}$ selama 1,5 jam dan selanjutnya pada suhu 550$600^{\circ} \mathrm{C}$ selama 2,5 jam. Setelah itu tanur dimatikan dan didiamkan selama semalam. Kemudian dinginkan pada desikator lalu timbang.

Perhitungan kadar C-organik dapat dilakukan terlebih dahulu dengan cara menghitung kadar bahan organik, yaitu menggunakan persamaan :

$$
\text { Bahan organik }=\frac{\text { Berat sampel }- \text { BST }}{\text { Berat sampel }} \times 100
$$

Ket: BST $=$ Berat setelah tanur

Setelah diketahui \% bahan organik kemudian dikalikan dengan 0,58 untuk mengonversi kandungan bahan organik ke dalam \%C-organik

$\% C-$ organik $=\%$ Bahan organik $x 0,58$
Setelah kadar C-organik diketahui, langkah selanjutnya adalah menghitung biomassa serasah yang dilakukan dengan cara menimbang sampel pada berat kering konstan [10]. Biomassa dapat ditentukan menggunakan persamaan :

$$
\text { Biomassa }=\frac{B K \text { sub contoh }}{B B \text { sub contoh }} x \text { total } B B \text { contoh }
$$

Keterangan:

$\mathrm{BK}=$ berat kering $\mathrm{BB}=$ berat basah

Setelah nilai biomassa didapat, penentuan kandungan karbon dapat dihitung dengan mengalikan biomassa dengan nilai estimasi karbon pada bahan organik. Perhitungan dapat dilakukan dengan persamaan berikut:

Estimasi $C$ serasah $=$ Biomassa $x$ kadar $C$ organik

Tingkat Serapan Karbon dioksida pada Hutan Mangrove

Konversi stok karbon ke total serapan $\mathrm{CO}_{2}$ dapat menggunakan perbandingan massa atom relatif $\mathrm{C}$ dapat dirumuskan sebagai berikut:

$$
\mathrm{CO}_{2}=\mathrm{Cn} \times 3,67
$$

3,67 = Angka ekuivalen atau konversi unsur $\mathrm{C}$ ke $\mathrm{CO} 2$ (massa atom $\mathrm{C}=12$ dan $\mathrm{O}=16, \mathrm{CO}_{2=}$ $(1 \times 12)+(2 \times 16)=44 ;$ konversinya $(44: 12)=3,67)$ [6].

\section{Kerapatan Mangrove}

Persentase kerapatan mangrove dilakukan dengan 2 metode yaitu hemisperichal photography dan perhitungan INP. Metode hemisperichal photography membutuhkan kamera berlensa fish eye dengan sudut pandang $180^{\circ}$ pada 1 titik pengambilan foto. Teknik ini masih cukup baru digunakan di Indonesia pada hutan mangrove, penerapannya mudah dan menghasilkan data yang lebih akurat. 

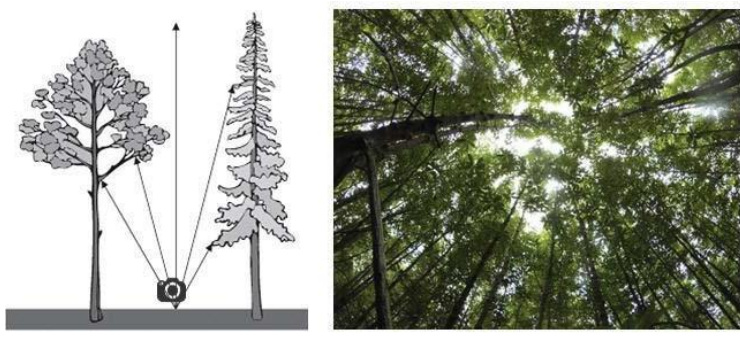

Gambar 2. Ilustrasi metode hemisperichal photography untuk mengukur tutupan mangrove

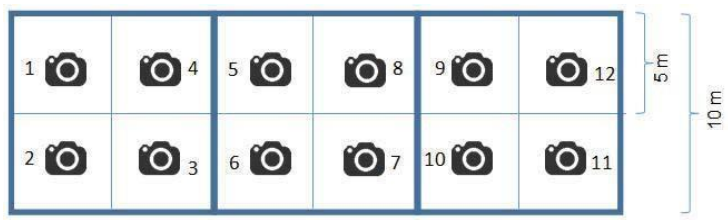

Gambar 3. Ilustrasi titik pengambilan foto dalam setiap plot pemantauan.

Kerapatan jenis juga dihitung menggunakan cara manual untuk memastikan keakuratan data. Pengambilan data kerapatan jenis mangrove dilakukan pada plot penelitian yang telah dibuat. Setiap plot penelitian, dilakukan identifikasi jenis tegakan mangrove, demikian pula dengan pencatatan jumlah individu tiap jenisnya tegakan mangrove. Data yang diperoleh, kemudian diolah berdasarkan persamaan sebagai berikut:

$$
D i=n i / A
$$

Keterangan:

$\mathrm{Di}=$ Kepadatan individu jenis ke-i (indv $/ \mathrm{m}^{2}$ ) ni $=$ Jumlah individu jenis ke-i yang diperoleh $\mathrm{A}=$ Luas total area pengambilan contoh $\left(\mathrm{m}^{2}\right)$

\section{HASIL DAN PEMBAHASAN}

\section{Tingkat Tutupan dan Kerapatan Mangrove}

Tabel 2 . Hasil analisis kerapatan mangrove di lokasi penelitian

\begin{tabular}{cccc}
\hline Stasiun & Jenis & $\begin{array}{c}\text { Jumlah } \\
\text { Individu }\end{array}$ & $\begin{array}{c}\text { Kerapatan } \\
\text { (indv/ha) }\end{array}$ \\
\hline I & A. marina & 166 & 5533.333 \\
II & A. marina & 131 & 4366.667 \\
III & A. marina & 123 & 4100 \\
IV & R. mucronata & 2 & 200 \\
& A. marina & 117 & 5500 \\
\hline
\end{tabular}

Analisis tingkat tutupan mangrove (mangrove cover) juga dilakukan dengan menggunakan teknik hemispherical photography. Konsep analisis ini adalah pemisahan piksel langit dan tutupan vegetasi, sehingga persentase jumlah piksel tutupan kanopi vegetasi mangrove dapat dihitung dalam analisis gambar biner. Hasil analisis tutupan mangrove menggunakan teknik hemispherical photography disajikan pada Tabel 3.

Tabel 3. Hasil Analisis Tutupan Mangrove Menggunakan teknik hemispherical photography

\begin{tabular}{cccc}
\hline Stasiun & Jumlah jenis & Jenis Dominan & $\begin{array}{c}\text { Tutupan } \\
(\%)\end{array}$ \\
\hline I & 166 & A. marina & 85.75 \\
II & 131 & A.marina & 76.98 \\
III & 123 & A.marina & 61.48 \\
IV & 2 & R. mucronata & 83.56 \\
& 117 & A.marina & \\
\hline & Rata-rata & & 76.94
\end{tabular}

\section{Kandungan Karbon pada Tegakan Mangrove}

Tabel 4. Estimasi Cadangan Karbon pada Tegakan Mangrove

\begin{tabular}{lll}
\hline Stasiun & Cn & WCO2 $_{2}$ \\
\hline I & 59.395 & 217.783 \\
II & 48.972 & 179.565 \\
III & 28.432 & 104.252 \\
IV & 53.457 & 196.007 \\
\hline
\end{tabular}

Keterangan: $\mathrm{Cn}$ (kandungan karbon), $\mathrm{WCO}_{2}$

(kemampuan penyerapan $\mathrm{CO}_{2}$ )

Berdasarkan hasil penelitian dapat diketahui bahwa pada stasiun I dengan jumlah pohon 166 buah memiliki biomassa sebesar 126,373 ton/ha serta memiliki kandungan karbon sebesar 59.395 ton/ha. Stasiun II dengan jumlah pohon 131 buah memiliki biomassa 104,196 ton/ha dengan kandungan karbon sebanyak 48,972 ton/ha. Stasiun III dengan jumlah pohon 123 memiliki biomassa 60,494 ton/ha serta menyimpan karbon sebanyak 28,432 ton/ha. Stasiun IV dengan jumlah pohon 119 buah memiliki biomassa 113,737 ton/ha dan menyimpan karbon sebanyak 53,547 ton/ha. Jumlah pohon yang lebih banyak dapat menyimpan karbon dalam jumlah tinggi, namun untuk hasil perhitungan pada stasiun I dengan jumlah pohon 166 menyimpan karbon 59.395 ton/ha, sedangkan pada stasiun IV dengan jumlah 
pohon 119 menyimpan karbon sebesar 53,547 ton/ha. Hasil yang diperoleh menunjukkan bahwa jumlah pohon yang tinggi tidak selalu memiliki simpanan karbon yang tinggi pula. Perbedaan kandungan karbon juga ditentukan oleh jenis spesies, dalam penelitian di stasiun IV jenis A. marina sebanyak 44 buah dapat menyimpan karbon sebanyak 40,163 ton/ha sedangkan jenis R.mucronata dengan jumlah pohon 2 buah dapat menyimpan karbon sebanyak 52,175 ton/ha. Stok karbon tersimpan ditentukan oleh biomassa yang dapat diamati di lapangan yaitu berdasarkan pengukuran diameter pohon. Suatu plot pengamatan memiliki pohon berukuran lebih besar dari plot yang lain dan mengidentifikasi bahwa biomassa dalam plot tersebut besar, sehingga simpanan karbon juga besar. Vegetasi mangrove sangat dipengaruhi oleh besarnya biomassa yang dimiliki, nilai biomassa vegetasi yang besar maka menghasilkan konversi nilai karbon yang juga besar. juga menyatakan bahwa terjadinya penyerapan karbon dioksida memiliki hubungan dengan biomassa tegakan. Suatu kawasan dapat memperoleh jumlah biomassanya dari produksi dan kerapatan. Produksi dan kerapatan tersebut berasal dari hasil pendugaan pengukuran diameter, atau tinggi tanaman, berat jenis, dan atau kepadatan setiap jenis pohon, serta kesuburan tanah [11].

\section{Kandungan Karbon pada Sedimen}

Tabel 5. Hasil Cadangan kandungan bahan organik dan estimasi cadangan karbon pada sedimen

\begin{tabular}{|c|c|c|}
\hline Stasiun & Cn (ton/ha) & WCO2 (ton/ha) \\
\hline I & 123.819 & 454.003 \\
\hline II & 112.479 & 412.423 \\
\hline III & 102.653 & 376.394 \\
\hline IV & 141.654 & $\underline{519.398}$ \\
\hline
\end{tabular}

Ket: $\mathrm{Cn}$ (stok karbon), $\mathrm{WCO}_{2}$ (serapan $\left.\mathrm{CO}_{2}\right)$

Berdasarkan hasil penelitian menunjukkan bahwa kandungan karbon sedimen terendah berada pada stasiun III yaitu memiliki kandungan karbon 102,653 ton/ha, sedangkan kandungan karbon tertinggi berada pada stasiun IV yaitu memiliki rata-rata 141,654 ton/ha. Stasiun III mempunyai kandungan karbon sedimen rendah dikarenakan tingkat kerapatan pada stasiun III juga paling rendah, sehingga dimungkinkan serasah yang gugur di atas permukaan sedimen masih dalam jumlah yang relatif sedikit. Serasah yang gugur merupakan asupan bahan organik yang penting dalam rantai makanan di dalam lingkungan perairan sehingga ketika kerapatan dalam suatu stasiun rendah maka serasah yang akan gugur juga sedikit. Stasiun IV mempunyai kadar bahan organik dan kandungan karbon tertinggi, hal ini dikarenakan kondisi substrat distasiun IV, merupakan substrat yang banyak terdapat cangkang gastropoda dan umur mangrove di lokasi tersebut lebih tinggi dibandingkan dengan stasiun lainnya, faktor lain yng mempengaruhi adalah tingkat sedimentasi di Desa Bedono tergolong tinggi, karena salah satu faktor yang mempengaruhi tinggi rendahnya kadar bahan organik dan karbon tanah adalah letak topografi tanah serta kondisi antropogenik yang mempengaruhi. Kadar organik pada tanah termasuk sedimen sangat sensitif terhadap sejumlah faktor, diantaranya adalah iklim, topografi, tanah dan pengelolaan tanaman, serta kondisi antropogenik lainnya [12].

\section{Kandungan Karbon pada Serasah Daun Mangrove}

Tabel 6. Kandungan karbon pada serasah daun mangrove

\begin{tabular}{|c|c|c|c|}
\hline Stasiun & $\begin{array}{c}\text { Biomassa } \\
\text { (ton/ha/hari) }\end{array}$ & $\begin{array}{c}\mathrm{Cn} \\
\text { (ton/ha/hari) }\end{array}$ & $\begin{array}{c}\mathrm{WCO}_{2} \\
\text { (ton/ha/hari) }\end{array}$ \\
\hline I & 0.00665 & 0.00043 & 0.001586 \\
\hline II & 0.00611 & 0.00039 & 0.001423 \\
\hline III & 0.0060 & 0.00041 & 0.001504 \\
\hline IV & 0.00620 & 0.00042 & 0.001546 \\
\hline
\end{tabular}

Keterangan: $\mathrm{Cn}$ (kandungan karbon), $\mathrm{WCO}_{2}$ (kemampuan penyerapan $\mathrm{CO}_{2}$ )

Berdasarkan hasil yang telah didapatkan dapat diketahui nilai kandungan karbon pada serasah daun mangrove tertinggi berada pada stasiun I dengan rata-rata 0.00043 ton/ha/hari, serta kandungan karbon pada serasah daun mangrove terendah terdapat pada stasiun II yaitu sebesar 0.00039 ton/ha/hari. Tinggi rendahnya kandungan karbon pada serasah daun mangrove dipengaruhi oleh laju produksi serasah selain itu kerapatan, jenis mangrove juga akan mempengaruhi laju produksi serasah daun mangrove, dimana laju produksi tersebut yang akan mempengaruhi tinggi rendahnya karbon yang tersimpan pada serasah daun mangrove. Jenis mangrove yang sama dengan umur berbeda akan memiliki laju produksi serasah yang 
berbeda pula, mangrove dengan jenis Rhizopora memiliki serasah daun yang lebih banyak pada jenis mangrove yang lebih tua atau optimum. Apabila umur mangrove melebihi titik optimum, maka serasah yang jatuh akan berkurang, karena pada batang mangrove tua, bagian dalamnya mulai keropos sehingga tajuk pohon mulai menyempit, dan produksi serasah berkurang. Stasiun IV mempunyai kandungan karbon tertinggi kedua setelah stasiun I, namun di stasiun IV hanya memiliki tingkat kerapatan sebesar 3500 indv/ha, hal ini dikarenakan pada stasiun IV satu-satunya stasiun yang memiliki spesies Rhizopora, dimana dijelaskan bahwa spesies Rhizopora menghasilkan serasah daun yang lebih banyak sehingga karbon yang ada pada stasiun IV lebih tinggi walaupun tingkat kerapatannya rendah [13].

\section{KESIMPULAN}

Kandungan karbon yang ada pada tegakan mangrove sebesar 190,257 ton/ha dengan tingkat kemampuan penyerapan karbon dioksida dari atmosfer sebesar 697,607 ton/ha. Kandungan karbon pada sedimen mangrove sebesar 480,608 ton/ha dengan kemampuan menyerap karbon dioksida dari atmosfer sebesar 1762,218. Sedangkan kandungan karbon pada serasah daun mangrove sebesar 0,00165 ton/ha/hari dengan kemampuan penyerapan karbon dioksida dari atmosfer sebesar 0,00606 ton/ha/hari.

\section{DAFTAR PUSTAKA}

[1] Nasprianto, D.M. H. Mantiri, T. L. Kepel, R. N. A. Ati Dan A. Hutahaean "Distribusi Karbon di Beberapa Perairan Sulawesi Utara (Carbon Distribution In North Sulawesi Waters)" J. MANUSIA DAN LINGKUNGAN, vol. 23, no. 1, pp 34-41, 2016.

[2] Sondak, C.F.A"Estimasi potensi penyerapan karbon biru (blue carbon) oleh hutan mangrove Sulawesi Utara" Jurnal of Asean Studies on Maritime Issues, vol. 1,no.1, pp 24-29, 2015.

[3] Donato, D.C., Kauffman, J.B., Murdiyarso, D., Kurnianto, S., Stidham, M. dan Kanninen, M. "Mangrove Salah
Satu Hutan Terkaya Karbon di Daerah Tropis", Brief CIFOR, no 12, pp 1- 12, 2012.

[4] Bachmid, F., Sondak, C., dan Kusen, J. Estimasi penyerapan karbon hutan mangrove Bahowo Kelurahan Tongkaina Kecamatan Bunaken. Jurnal Pesisir Dan Laut Tropis, vol. 6, no.1, pp 8-13, 2018.

[5] Kusumaningtya. M. A., A. A. Hutahaean, H. W. Fischer, M. Pérez-Mayo, D. Ransby dan Tim C. Jennerjahn "Variability in the organic carbon stocks, sources, and accumulation rates of Indonesian mangrove ecosystems" Estuarine, Coastal and Shelf Science, pp 310-323, 2019.

[6] Martha., P. Peñaranda, J. R. C. Kintz, Enrique dan P. Salamanca "Carbon stocks in mangrove forests of the Colombian Pacific”, Manuscript, pp 1-15, 2019.

[7] Suryono., N Soenardjo., E Wibowo., R Ario dan E Fahrur Rozy "Estimasi Kandungan Biomassa dan Karbon di Hutan Mangrove Perancak Kabupaten Jembrana, Provinsi Bali’ Buletin Oseanografi Marina, vol. 7, no.1, pp 1-8,2018.

[8] Howard, J., Hoyt, S., Isensee, K., Telszewski, M., Pidgeon, "Coastal Blue Carbon: Methods for assessing carbon stocks and emissions factors in mangroves, tidal salt marshes, and seagrasses. Conservation International, Intergovernmental Oceanographic Commission of UNESCO, International Union for Conservation of Nature" Arlington, Virginia, USA, 2014.

[9] Association of Official Agriculture Chemist "Official Methods of analysis of AOAC International”, pp 25-237,2002.

[10] Hairiah K, Ekadinata A, Sari RR, Rahayu S "Pengukuran Cadangan Karbon: dari tingkat lahan ke bentang lahan" World Agroforestry Centre, ICRAF SEA Regional Office, University of Brawijaya (UB), Malang, Indonesia, 2011.

[11] Heriyanto, N. M., Subiandono, E., dan Karlina, E "Potensi dan sebaran nipah 
(Nypa fruticans (Thunb.) Wurmb) sebagai sumberdaya pangan (Potency and distribution of Nypa palm (Nypafruticans (Thunb.) Wurmb) as food resource)" Jurnal Penelitian Hutan dan Konservasi Alam, vol. 8, no.4, pp 18,2011 .

[12] Widiatmaka, "Urgensi penjagaan karbon dalam tanah dalam rangka mitigasi dan adaptasi perubahan iklim" Prosiding International Seminar of Adaptation and Mitigation on Climate Change. Padang 11 Maret, 2013.

[13] Zamroni, Y., dan Rohyani, I. S "Litterfall production of mangrove forest in the beach waters of sepi bay, west lombok", Biodiversitas Journal of Biological Diversity, vol. 9, no.4, pp 1-10, 2008. 
